\title{
Architectural and Structural Requirements on Building Permits to Reduce Earthquake Risk. The Case of Surabaya, Indonesia
}

\author{
Adjie PAMUNGKAS ${ }^{*}$, Kesumaning Dyah LARASATI², Data IRANATA3 \\ *Corresponding author \\ ${ }^{1}$ Institut Teknologi Sepuluh Nopember, Department of Urban and Regional Planning, Surabaya, INDONESIA \\ ${ }^{2}$ Development Initiatives for Indonesia (DIFI), Surabaya, INDONESIA \\ 3 Institut Teknologi Sepuluh Nopember, Department of Civil Engineering, Surabaya, INDONESIA \\ $\triangle$ adjie@urplan.its.ac.id (i) https://orcid.org/oooo-ooo1-9251-1681 \\ $\triangle$ kesumaningdyahlaras@gmail.com (D) https://orcid.org/oooo-ooo1-8910-1526 \\ $\triangle$ data@ce.its.ac.id (D) https://orcid.org/oooo-0oo2-2988-3316
}

DOI: 10.24193/JSSP.2021.2.04

https://doi.org/10.24193/JSSP.2021.2.04

K e y w o r d s: earthquake resilience, building architecture, building structure, earthquake risk

\begin{abstract}
A B S T R A C T
The Indonesian Earthquake Centre has discovered two fault zones in Surabaya, causing a 6.5 magnitude earthquake in 2017. Since Indonesia lies in the ring of fire area, the national government has stipulated several earthquake-building regulations. However, with no history of significant earthquakes, Surabaya has no strict local building regulations to reduce the new risk. Previous studies indicate that simple buildings in Surabaya are the most vulnerable during any earthquake events. Simple buildings, as permanent and semipermanent constructions, dominate in the category of residential buildings in Surabaya. Furthermore, vulnerable buildings are the primary cause of fatalities and injuries during earthquake events. Consequently, the revision of current local building regulations is the key milestone to reduce the earthquake risk in Surabaya. This paper evaluates current local and national building regulations by using content analysis of in-depth interviews and focus group discussion data, and then proposes adjustments to the local regulations to increasing the resilience degree of constructions in Surabaya. The modifications on current local regulations are mainly related to the shape of the building and the material used for façades and building safety analysis (load factor analysis and collapse scenarios).
\end{abstract}

\section{INTRODUCTION}

In 2017, the Indonesian National Earthquake Centre released an earthquake risk map containing two potential faults zones in Surabaya, namely Waru and Surabaya Faults, which are part of the Kendeng Thrust (Pusat Gempa Nasional [PUSGEN], 2017; Koulali et al., 2016). These faults can cause a 6.5 magnitude earthquake, thus placing Surabaya City in East Java Province at risk (Fig. 1). As a centre of development in the eastern part of Indonesia, especially in East Java
Province, Surabaya experiences a steady economic growth indicated by IDR 57.37 trillion (4.03 billion USD) of investments in 2018 and $13.95 \%$ land conversion into built-up areas in the period 2001-2015. Furthermore, the city allowed the construction of 27 high-rise buildings in 2012, and this number continued to increase up to 85 in 2015 (Effendi, 2018; Zulkarnain, 2016; Pamungkas et al., 2019). These developments show the importance of Surabaya as a critical city in Indonesia. Regarding the potential earthquake hazard, Pamungkas et al. (2019) indicated that Surabaya has a 
low level of resilience to earthquakes from the institutional perspective (score 2.58 out of 5 ). The leading causes for this low resilience are the limited experience with this type of issue and the fact that this hazard has only recently been recognized. Furthermore, the city scored very low in the case of another subindicator: the integration of risk measures in housing plans and policies (1.68 out of 5). In addition, many buildings in Surabaya are prone to earthquakes, increasing this risk. Irawan et al. (2019) and Riyanto et al. (2020) conducted building assessments via RViSITS and found that $21 \%$ of 98 high-rise buildings are vulnerable. Meanwhile, about 33\% out of 206 samples of permanent construction buildings and $67 \%$ of 33 samples of semi-permanent construction buildings fit into the vulnerable category. About $40 \%$ of the Surabaya area is the settlement where landed house settlements (simple buildings) dominate more than vertical houses (Firmansyah et al., 2018; Surabaya City Government, 2015). As many as $85.7 \%$ of houses in Surabaya are already permanent, whilst $8.5 \%$ are still semi-permanent (Surabaya City Government, 2015).

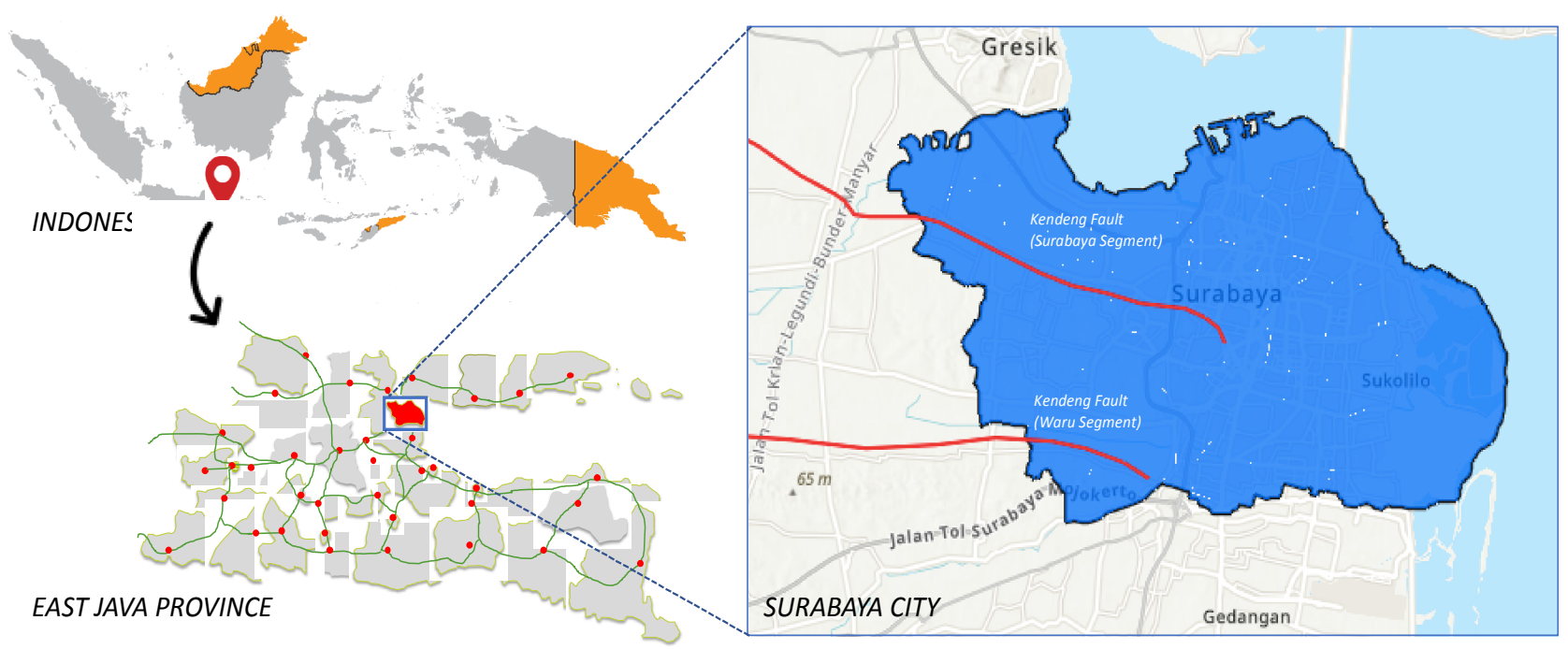

Fig. 1. Orientation of Surabaya City and the two fault zones crossing it (source: PUSGEN, 2017).

From an ideal perspective, plans and regulations are crucial in reducing the impact of earthquakes. Cross (2015) stated that even though Concepcion, Chile was hit by the sixth-largest earthquake ever recorded, fatalities were less than 1,00o because of effective building regulations. Munich Re, NatCat Service 2013 from the World Bank (2015) also noted that over the past ten years, high-income countries with advanced building codes have faced $47 \%$ of disasters globally, but only suffered $7 \%$ of disaster fatalities. Srividhya et al. (2020), Ipong et al. (2020) and Gautam and Chaulagain (2016) highlighted the importance of building strength in minimizing the impacts of earthquakes in many of the past earthquake events. Therefore, the cities that survive from devastating earthquakes are those that successfully implement disaster resilient building regulations.

Understanding the new hazard, future development, building vulnerability, and the ideal concept of building regulations, Surabaya may have a high risk of earthquake due to its significant number of vulnerable buildings. Issuing permits to properly constructed buildings can reduce potential fatalities and injuries affected by collapsed buildings. Therefore, this paper will assess current building regulations in Surabaya, particularly regarding architectural and structural requirements. Based on this assessment, the paper will propose improvements for building regulations in Surabaya.

\section{THEORY AND METHODOLOGY}

The potential earthquakes in Surabaya may cause severe damages to buildings. Tamara (2011) concludes that significant earthquakes in various countries can cause damages to buildings due to inadequate regulation, making many buildings poorly on the ground. This study refers to the theory of building resilience, which means the ability of buildings and their supporting elements to survive, recover quickly from disaster stress and damage, and adapt to changing circumstances (Barret and Constas, 2014). These theories should be accommodated in public regulation to be the primary reference for the city dwellers to propose construction projects and for the local government to enact the regulation in permitting the building and earthquake risk reduction. The modification of building regulations according to these theories may reduce building vulnerability and become part of making city resilience. Architectural and structural requirements are the central concern of building permit regulation, called Izin Mendirikan Bangunan (IMB) in Indonesia. In the case of Surabaya building permits regulation, building types are 
categorised as simple, non-simple, and specific. This paper discusses only two types of buildings, namely simple and non-simple. Tamara (2011) suggested that structural design is the leading cause of the collapsed buildings. In comparison, Giuliani (2000) viewed that the architectural aspect of the building can reduce its vulnerability to earthquakes. Therefore, these two key aspects are the main subjects of discussion in this paper, as presented in Table 1.

Table 1. Variables for building's architectural and structural requirements.

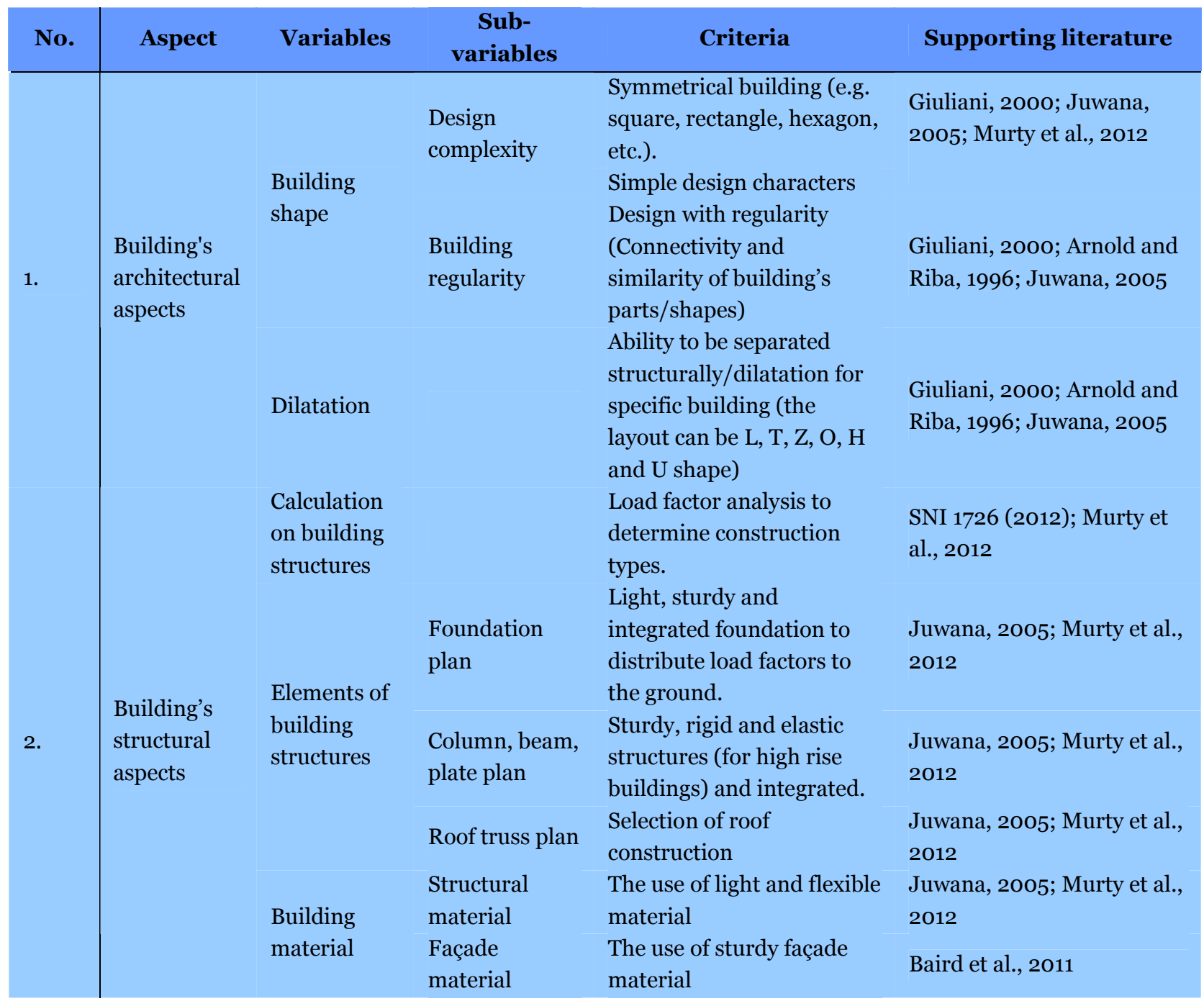

This paper uses qualitative research by exploring relevant secondary data supported by stakeholders' judgments. Mack et al. (2005) considered this type of research important in making systematic, factual, and scientific descriptions. Groat and Wang (2013) added that interpreting all information from secondary data (both from theory and regulations) can be a conclusive source in this type of research. Specifically, this paper utilizes content analysis to uncover the main ideas from collected documents and reach a logical conclusion on shared ideas or contexts (Bungin, 2010; Krippendorff, 2004). Key literature and standards, including the Federal Emergency Management Agency (FEMA) and Uniform Building Code (UBC), enrich the various ideas delivered by the respondents. Since the paper aims to propose improvements for building regulations, the two objectives in this paper are to analyze the current regulation gap and propose recommendations for building regulation in terms of earthquake resilience (Fig. 2).

The first stage of the analysis in this paper is to understand the current regulation. Afterward, representatives of six key stakeholders discuss current regulations and their gap in reducing earthquakes risks. The six key stakeholders are the Local Housing and Settlement Agency - Dinas Perumahan Rakyat, Kawasan Permukiman dan Cipta Karya Tata Ruang (DPRKP CKTR), an urban planning consultant, a highrise building developer, the Indonesian Institute of Architects - Ikatan Arsitek Indonesia (IAI) and academics from urban planning, as well as civil 
engineering. The discussion results in the first draft of the revision on the current building regulations.
Subsequently, the Surabaya government expert panel for building permits discuss the draft.

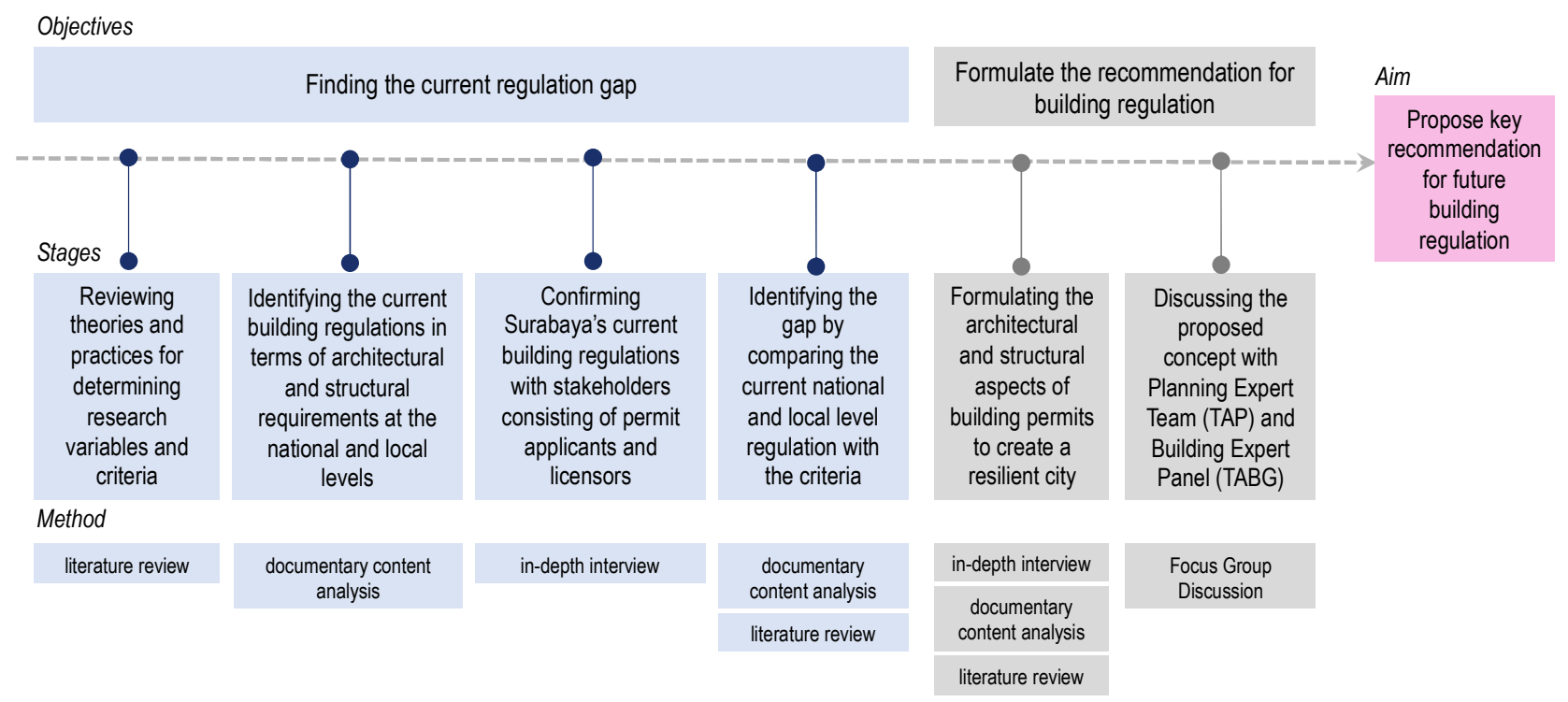

Fig. 2. Steps in formulating building regulations to increase building resilience to earthquakes in Surabaya.

This expert panel consists of two teams, namely Tim Ahli Perencana - TAP (Planning Expert Team) and Tim Ahli Bangunan dan Gedung - TABG (Building Expert Team). These expert panels consist of 11 experts in architecture, civil engineering, and urban planning. Based on their task to evaluate building permits, both teams were selected as the critical

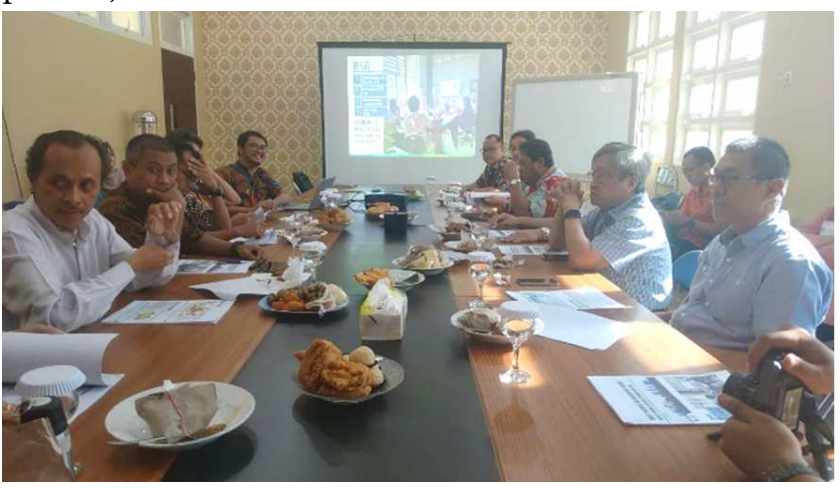

Fig. 3. Focus group discussion among TAP and TABG on 11 October 2019.

\section{RESULTS AND DISCUSSION}

\subsection{Current regulations}

At the national level, the central regulation related to building constructions is the Regulation of the Minister of Public Work and Public Housing No. 05/PRT/M/2016 on Building Permits. At the national level, SNI 1726 of 2012 also contains building construction and design standards specifically for earthquakes. These two regulations are the primary references for local regulations in managing building permits. Surabaya has three principal regulations used as critical references for issuing building permits at the local level, including the spatial plan. Based on the respondents for the Focus Group Discussion (FGD) in the last phase of analysis. The two teams offered effective responses for updating the first draft elaborated (Fig. 3).

After the discussion with TAP and TABG, the formulation of building permit requirements is finalized.

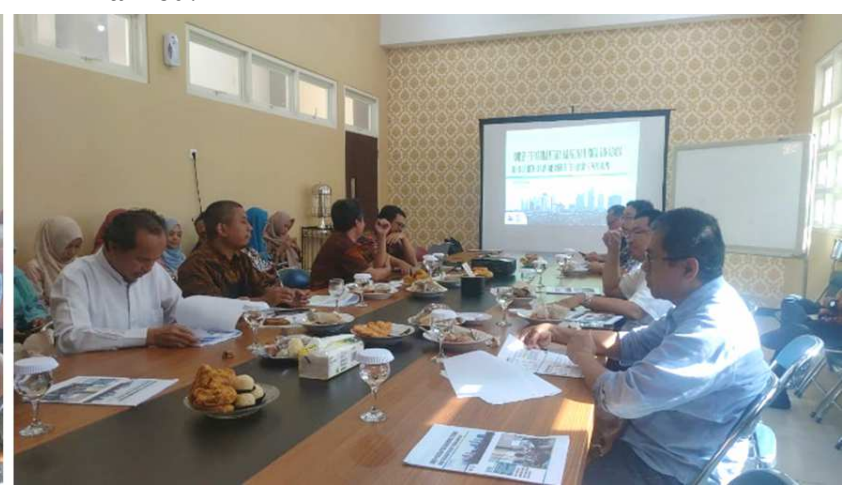

Mayoral Decree No. 13 of 2018, simple buildings have only 1-2 floors with a maximum land parcel of $500 \mathrm{~m}^{2}$. In contrast, non-simple buildings have land parcels of more than $500 \mathrm{~m}^{2}$, allotted for residential and nonresidential uses. Figure 4 illustrates current situation of building varieties in Surabaya. Based on the local regulation, current architectural requirements state that building proposals must provide information on the building design. Simple buildings must provide an architectural drawing illustrated using manual sketch or CAD. For the non-simple buildings, the architectural drawing consists of more detailed information such as the site plan, layout, top view, front view, cross-section, and long section. There are no regulations on building shapes and dilatation. 
The current structural requirements of buildings stipulate that the proposal for non-simple buildings must provide the load factor calculation of the building structure; a foundation plan; a column, beam, and slab plan; and structural material. However, the proposal
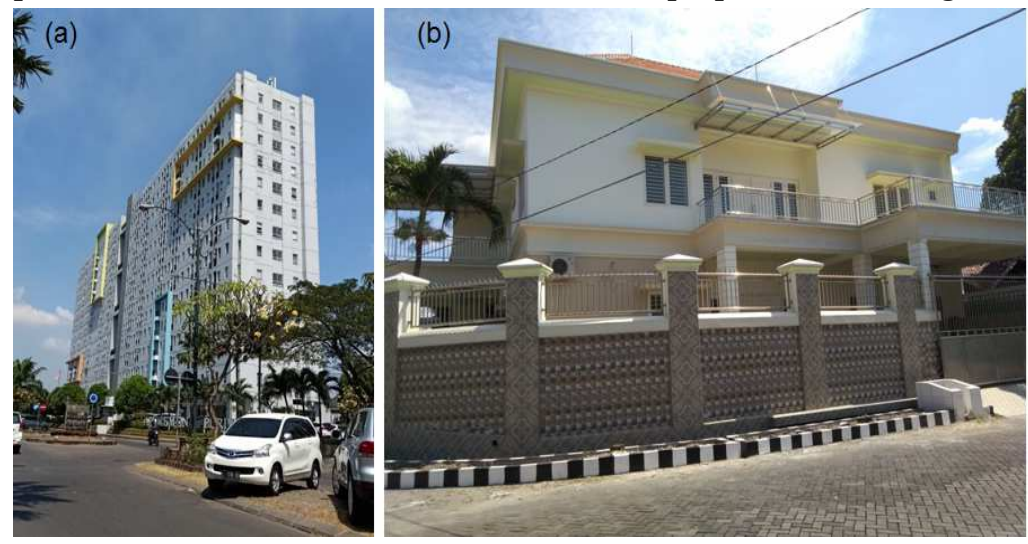

(c)

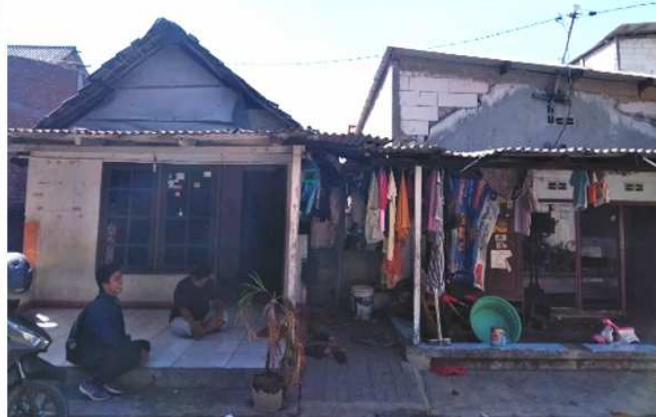

Fig. 4. Examples of (a) non-simple building, (b) simple building with permanent construction, (c) simple building with semipermanent construction (source: RViSITS building survey, 2018).

Table 2. Relevant building permit regulations at the national and local level.

\begin{tabular}{|c|c|c|c|}
\hline No. & Level & Regulation types & Current regulations \\
\hline \multirow{4}{*}{1.} & \multirow{4}{*}{ National } & Act & Act No. 28 of 2002 on Buildings \\
\hline & & Government regulation & Government Regulation No. 36 of 2005 on Buildings \\
\hline & & Ministerial regulation & $\begin{array}{l}\text { Regulation of the Minister of Public Works No. 29/PRT/M/2006 } \\
\text { on Guidelines on Technical Requirements for Buildings. } \\
\text { Regulation of the Minister Public Work and Public Housing No. } \\
\text { 05/PRT/M/2016 on Building Permits. }\end{array}$ \\
\hline & & $\begin{array}{l}\text { Indonesia National } \\
\text { Standard (SNI) }\end{array}$ & $\begin{array}{l}\text { SNI } 1726 \text { of } 2012 \text { on Technical Planning for Building Structures } \\
\text { Resilience to Earthquake. }\end{array}$ \\
\hline \multirow{4}{*}{2.} & \multirow{4}{*}{ Local } & & Surabaya Local Regulation No. 7 of 2009 on Buildings jo \\
\hline & & Local regulation & $\begin{array}{l}\text { Surabaya Local Regulation No. } 6 \text { of } 2013 \text { on the Amendment of } \\
\text { Local Regulation No. } 7 \text { of } 2009 \text { on Buildings }\end{array}$ \\
\hline & & & Local Regulation No. 8 of 2018 on Surabaya Detailed Plan. \\
\hline & & Mayoral Regulation & $\begin{array}{l}\text { Mayoral Regulation No. } 13 \text { of } 2018 \text { on Technical Guidelines on } \\
\text { Building Permits. }\end{array}$ \\
\hline
\end{tabular}

\subsection{Architectural requirements}

\subsubsection{Building shape}

The national regulation regarding building shapes is quite clear. The regulation suggests that all buildings should have a symmetrical, regular and simple design to reduce the potential impact of earthquakes.

"Technical building requirements (...) include architectural building aspects; $a$. (...) should be as symmetrical and as simple as possible (...) b. the building layout should be centric (...) c. building shape (...) should be designed with consideration of structural stability and resilience to earthquakes" (Appendix in Ministerial Regulation No. 29/PRT/M/2006).
The local regulation does not explicitly include such clear guidance as in the case of national regulations. Instead, the local regulations direct the design linked to the characteristics of the surroundings, especially in specific zones (such as the old town area). The role of the building expert team is vital, since the building norms will mainly consider the technical considerations from this team:

"The mayor has the authority to enact the architectural building requirements (...). The requirements will consider the technical considerations from the building expert team" (Surabaya Local Regulation No. 6 of 2013).

Based on the in-depth interviews, the building expert team has no particular concern for the building shape. The local government considers that the national regulation on building shape is too strict. Therefore, the 
local regulation does not refer to the provisions laid down by the national regulation on the shape of the buildings.

"Not all (national) regulations are relevant to Surabaya. If it is too strict, we do not refer to it (...). About building shape; we are not limited to only squares or other shapes (specific regulation) (...)" (DPRKP CKTR Surabaya, o9 April 2019).

A lenient discretionary approach in local regulations is limited in responding to earthquake risks, as Surabaya has no tradition in managing earthquake risks. The new Indonesian earthquake map indicates that earthquakes are a new threat in Surabaya. To address this threat, symmetric, simple, and regular building shapes are considered more resilient to earthquakes than buildings with complex and irregular shapes (Giuliani, 2000; Juwana, 2005; Arnold and Riba, 1996; Murty et al., 2012). Arnold and Riba (1996) suggested that a simple building shape with regularity has a centralized building mass.

Figure 5 illustrates the proposed building shape based on these suggestions. A centralized building mass has low earthquake risk. Therefore, the symmetric, simple, and regularity-related considerations for the building shape are essential for minimizing the impact of an earthquake.

The implementation of strict building shape regulations is impractical. FEMA (2010) advised the requirement of a load factor analysis for every proposed building shape. A more flexible shape could be allowed, provided that the building design has a proper load factor analysis to minimize the risk. Based on the FGD, this mechanism is preferred since it offers flexibility while still providing disaster resilience.

"We will have difficulty in implementing the obligation for symmetric and simple building shapes. It will be difficult to achieve a good city landscape (monotone/uninteresting value) if the buildings - as one of the key factors of the landscape - are uniform and only shaped like boxes" (Architecture Expert in the Building Expert Team, 11 October 2019).

"I agree if the symmetricity, regularity, and simple building shape are only a recommendation rather than an obligation (...). For any building shape, if the building structure calculation is $O K$, the proposed building is still feasible (...) ensure that the building structure design is still capable of coping with the load of an earthquake" (Civil Engineering Expert in the Building Expert Team, 11 October 2019).

Since the flexibility improves the applicability of regulation, building permit requirements in Surabaya should be modified. This paper proposes a simple and symmetrical building shape as the primary requirement to be considered when issuing a building permit. If a proposed building has a complex, non-symmetrical, or irregular building shape, the proposal should include a load factor calculation for a potential earthquake with 6.5 magnitude. Local regulations should refer to SNI 112
1726 of 2012 and Regulation of the Minister of Public Works No. PU 29/PRT/M/2006 to incorporate the building shape criterion.

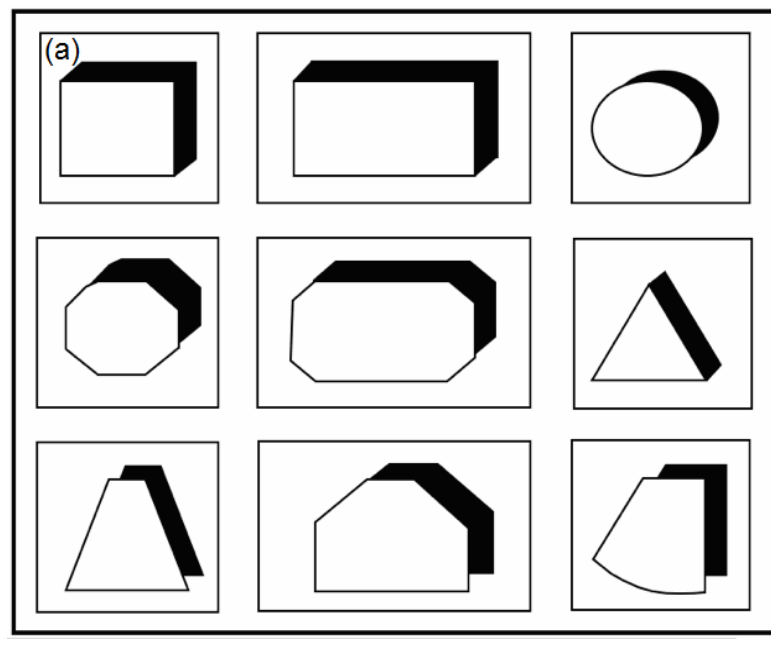

(b)

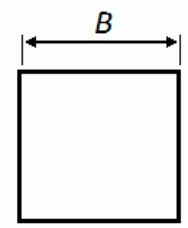

Square

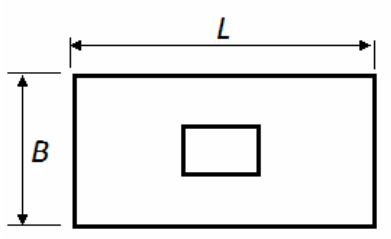

Rectangle box

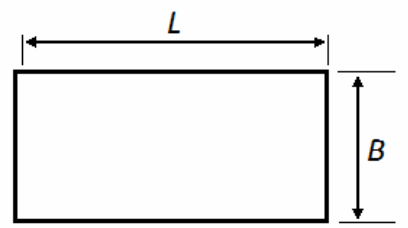

Rectangle

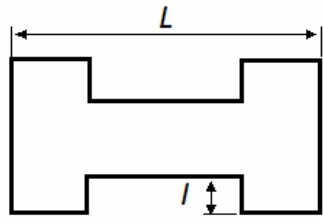

"I" with small projections

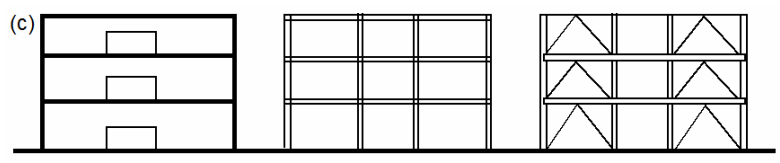

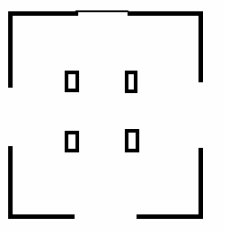

Shear Frame

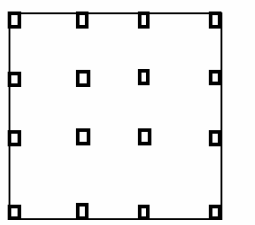

Moment Resistant Frame

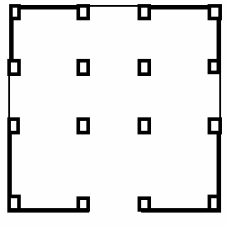

Braced Frame
Fig. 5. Simple, symmetrical, and regular building shape considerations (source: Arnold et al. 1981; Arya et al. 2014): (a) simple building shape; (b) symmetrical building shape; (c) regular building shape.

\subsubsection{Dilatation}

Dilatation refers to the structural division in buildings to avoid the attraction force (vertically or horizontally) from other parts of the building. Since earthquakes can cause dynamic movements of some parts of the building, dilatation can prevent other parts of a building from being affected by the dynamic movements of the earthquake. Juwana (2005) 
suggested that dilatation can avoid the cracking or collapsing of building structures due to vertical or horizontal movements. Dilatation is significant for certain buildings such as long buildings, on uneven land, high earthquake risk zones, and buildings with an L, T, Z, O, H, or U layout. Figure 6 illustrates building designs with dilatation. (a)

1.

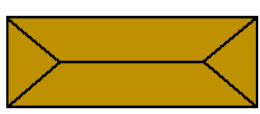

2.

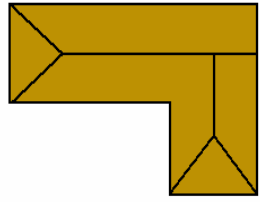

3.

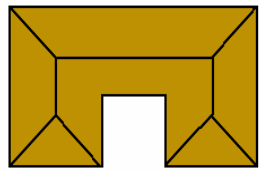

(b)

1.

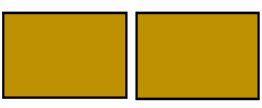

2.

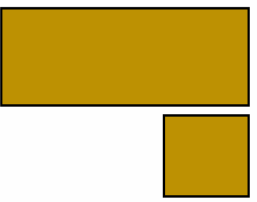

3.

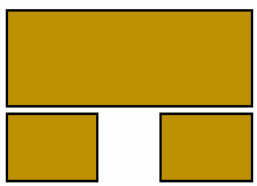

Fig. 6. Illustration of structural building division (dilatation): (a) Building without the dilatation concept; (b) Building with the dilatation concept.

Regarding national regulations, Act No. 28 of 2002 Article 14 and Government Regulation No. 6 of 2005 Article 24 regulate dilatation criteria. The Regulation of the Ministry of Public Works No. 29/PRT/M/2006 discusses dilatation in detail. These regulations require dilatation for buildings with $\mathrm{T}, \mathrm{L}$, or $\mathrm{U}$ shape to avoid earthquakes or land subsidence damage.

For the local context, Surabaya's local regulation does not explicitly refer to the national regulations above. The Local Regulation No. 7 of 2009 on Buildings jo Local Regulation No. 6 of 2013 did not explicitly regulate dilatation. Based on the local regulation, the recommendations of the building expert team (TABG) are the primary reference for permits from architecture building norms.

"The local building structure and architecture regulations still refer to the national regulation. However, not all national regulations are relevant for Surabaya (...) the feasibility of building architecture is regulated mainly in the Certificate of Building Functions (SLF), another process to be carried out after obtaining the building permit (IMB)" (DPRKP CKTR Surabaya, o9 April 2019).

An in-depth interview with a professional architect showed that dilatation is vital to ensure building resistance to earthquakes. Dilatation can be advisable for simple as well as non-simple buildings. If the proposed building has no dilatation design, it provides structural calculations to accommodate the earthquake load factor. Especially for non-simple buildings, the proposed building should also include building collapse scenarios due to earthquakes. The collapse scenarios can illustrate possible real situations in case of an earthquake event. Consequently, the evacuation route can be planned based on these collapse scenarios.

"Building shape (dilatation) can be more flexible than the building structure, but the structural calculation has to be correct, to resist the dynamic force (...) dilatation in buildings is considered safer (...)" (Architecture practitioner, 15 July 2019).

\subsection{Structural building requirements}

\subsubsection{Load calculation}

UBC (1997) suggested that every building must have good structural strength to comfort the residents and prevent structural failure and fatalities. Load calculation is a mechanism to ensure that a building has good structural strength. The relevant national regulations for load calculation are Act No. 28 of 2002 Article 17 and Government Regulation No. 6 of 2005, detailed in Regulation of the Ministry of Public Works No. 29/PRT/M/2006. These regulations stipulate load calculation to ensure that the building can accommodate regular and accidental loading types. The earthquake force is one of the examples of accidental loading. SNI 1726 (2012) provides the technical details for load calculation.

Surabaya's regulations on load calculation are in line with the national regulations. Local Regulation No. 7 of 2009 jo No. 6 of 2013 also requires proposed buildings to fulfil safety requirements, including load calculation. Unfortunately, there are no detailed safety requirements regarding potential earthquakes. In the regulations, fire and thunderstorms are the two types of regulated hazards.

“(...) Safety requirements include structural strength, the ability to prevent fire and cope with it, (...) thunderstorms (...)" (Local Regulation No. 6 of 2013).

The national and local regulations are coherent in including load factor calculation as one of the building safety requirements. DPRKP CKTR Surabaya Agency stated that the agency refers to SNI 1726 (2012) to evaluate the building structure.

"We refer to current regulations (...) and the good thing in the Building Expert Team meetings (is that) we are advised to add (...) how the building structure is planned, (...). For the (building) structure, we always follow the SNI (1726) (...)” (A developer in Surabaya, o2 April 2019).

In conclusion, the regulation on load calculation is already in place as a precondition for the local building permits. This paper proposes to include load calculation precisely to anticipate the potential earthquake risk as a response to the new hazard in Surabaya. 


\subsubsection{Building structure elements}

The building structure consists of the lower base structure (foundation) and upper base structure (column, beam, plate, roof frame, and cover). Tjokrodimulyo (2007) suggested that the main objective of the building structure is to prevent collapse due to an earthquake despite sustaining damage. UBC (1997) stated that the principle of building design is as follows, i.e., a small-scale earthquake will not damage the building; a medium-scale earthquake will damage the architectural parts, but not the structural parts; a large-scale earthquake will damage the building's structural and non-structural parts, yet not causing the building to collapse.

The national government has made special arrangements on building structures to achieve the objective above. Specifically, Act No. 28 of 2002 Article 17 and 18, Government Regulation No. 6 of 2005 Article 33, Regulation of the Ministry of Public Works No. 29/PRT/M/2006, and SNI 1726 (2012) are the key regulations in Indonesia. Based on these regulations, all building structures plan to be solid and stable to accommodate loads. In the case maximum loads cause buildings to collapse, the dwellers should still have time to escape.

Based on the literature and the national regulations above, building structures should be earthquake resilient. Notably, the building may sustain damage, but should not collapse. Furthermore, buildings must remain standing to give inhabitants time to escape. The regulations in Surabaya, particularly for non-simple buildings, follow this central idea. Specifically, Surabaya Regional Regulation No. 6 of 2013, Article 23 stipulates that the load calculations for non-simple buildings follow the national regulations.

"All buildings must be planned to meet the safety requirements. Safety requirements include structural strength, the ability to prevent and cope with hazards (...) (fire and thunderstorms). Structural strength (...) follows the reasonable technical standards (...)" (Local Regulation No. 6 of 2013, Article 23).

“(...) for IMB (building permits), all (local) regulations (...) refer to national regulations. (...) However, not all (some) regulations are adapted (for the local context). For example, the structural calculation is only applied for high-rise buildings (nonsimple buildings). For simple buildings, this calculation is not required ..." (DPRKP CKTR Surabaya City, og April 2019).

Unfortunately, the simple buildings (one and two-story buildings) in Surabaya have no arrangement regarding earthquake resilience. The local government does not refer to the national regulation for simple buildings, i.e., Regulation of the Ministry of Public Works and Public Housing No. 05/PRT/M/2016. In the Mayoral Decree No. 13 of 2018 on Building Permits, the 114 proposal for simple buildings does not require structural calculations and drawings. Therefore, Surabaya's regulations should be modified specifically for simple buildings. Moreover, the local regulations should refer to the Ministry of Public Works and Public Housing regulation.

“(...) Simple buildings, (...) do not need structural calculations. But (simple buildings) must be strong and have a strong connection among structures. This arrangement has been regulated (...) by the Ministry of Public Works. (Whether) Surabaya has referred to it, I think Surabaya has not yet (referred to it). The regulation for houses in Surabaya is simple" (Civil Engineering Expert, 21 May 2019).

\subsubsection{Building materials}

Building materials are an essential element to ensure a building's earthquake resilience. The Northridge Earthquake in 1994 showed that threethirds of building damage was related to non-building elements (Baird et al., 2011). The Christchurch Earthquake in 2011 showed a similar pattern, namely that the typical damage to buildings related to nonstructural elements could cause potential harm to the inhabitants. Furthermore, Baird et al. (2011) suggested that the non-structural elements are more vulnerable than structural elements in case of earthquake impact. BMKG also mentioned that the most common factor for injury during an earthquake is inhabitants exposed to falling structural and non-structural materials (BMKG, 2010). Consequently, regulations on building materials are essential to minimize the impact of an earthquake.

The primary national regulation is the Regulation of the Ministry of Public Works No. 29/PRT/M/2006. Among its provisions we learn that building materials should meet the safety requirement as stipulated in the Indonesian Standard (SNI). The safety requirement includes considerations for the safety of the surroundings and its inhabitants. Appendix II in the regulation of the Ministry of Public Work states that building permits require high-quality structural materials. On the other hand, Surabaya's local regulation does not explicitly refer to these national-level regulations. Nevertheless, since SNI applies to all Indonesian cities, all local governments should follow these national standards.

The in-depth interviews and FGD with the TAP and TABG in 2019 showed that both expert teams understand the importance of regulations on building façades to minimize the impact of earthquakes. The use of glass, for example, may have severe impacts on inhabitants during an earthquake. However, the implementation of this regulation in Surabaya is still questionable. No specific local regulation follows the SNI on façade arrangements. Furthermore, local experts still have different opinions on the importance of façade regulations in minimizing the impact of 
earthquakes. They argue that some façades have negative impacts on the inhabitants from an earthquake risk perspective. However, façades can also give positive contributions, such as providing an aesthetic value for the building or efficiency for green buildings.

"(...) in Dubai, (...) for earthquakes, they regulate the façade material of buildings. For breakable materials such as glass, ceramics (...) the inhabitants can be injured not by the structural collapse of the building, but by a collapsed façade, (...)" (Architectural Expert, 15 July 2019).

“... Façade regulations should be considered. Glass (for example) is considered hazardous material causing impact during an earthquake. On the other hand, energy efficiency or green buildings use glass as one of the building materials (...)" (Architecture Expert in Building Expert Team, 11 October 2019).
“... now, we have difficulty regulating building façade since the proposal can be changed and (there are) no (local) instruments for this regulation. This regulation can be proposed for future regulation but should be applied in selected risk-prone (areas)" (Civil Engineering Expert in Building Expert Team, 11 October 2019).

Based on the information above, the construction of simple and non-simple buildings in high-risk earthquake zones should comply with building façade regulations. The façade regulation includes structural materials that meet the SNI safety requirements; façade materials should minimize the potential impact of earthquakes, and the use of vulnerable façade material should consider its location, quality, and application of technology.

Table 3. Proposed modifications for the building regulations in Surabaya to minimise the impact of earthquakes.

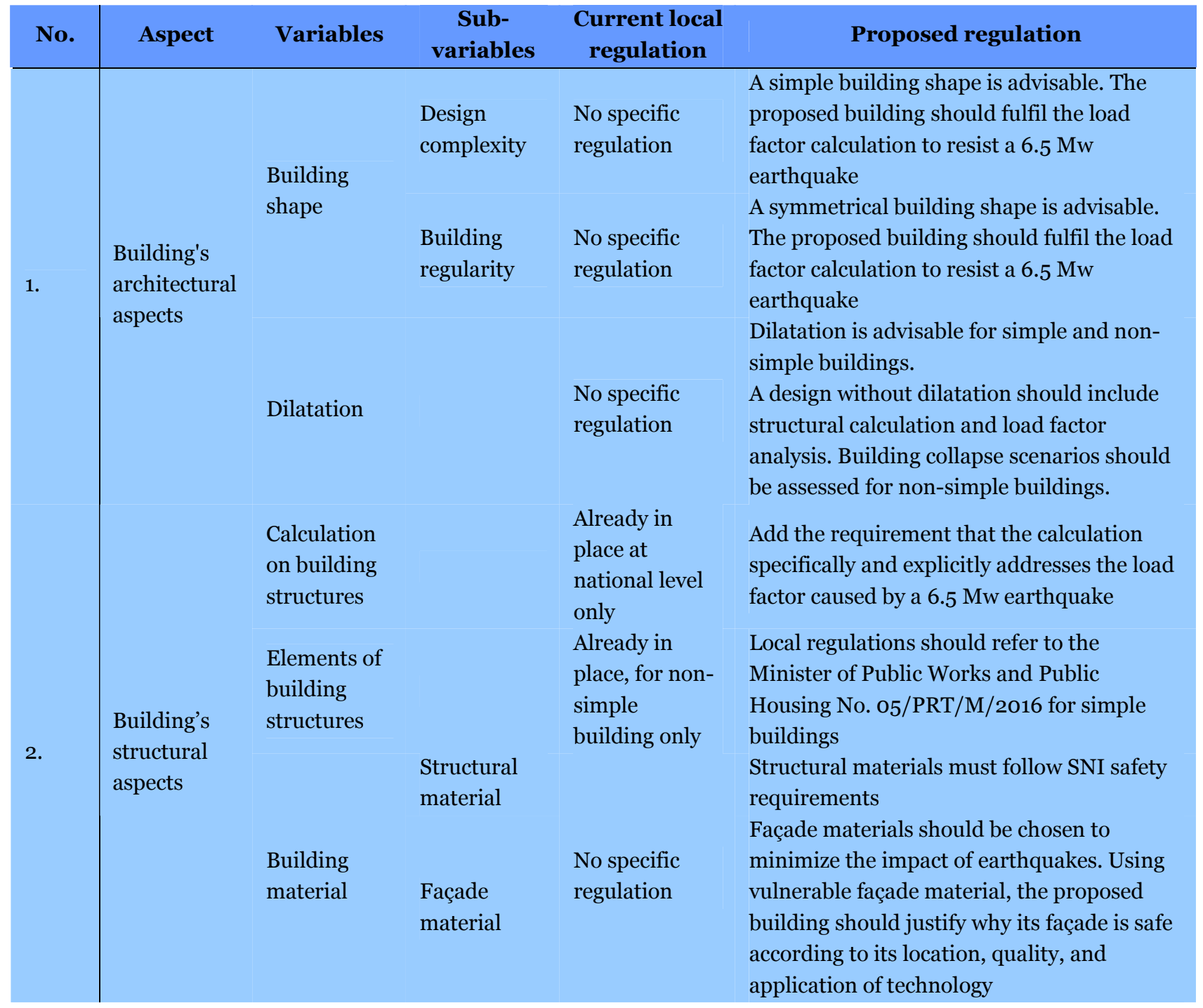

The discussion above resulted in two sides, the ideal side and the practical side. The ideal side, from the literature review, regulates each variable rigidly. From a practical standpoint, the likelihood of implementing this ideal side is minimal, mainly in terms of aesthetics, economy, preferences of building owners, and other 
relevant perspectives, which resulted in a need for some flexibility. The flexibility can be in the form of combining some related variables. Building structures calculations can be the primary reference. As long as the building meets the criteria for calculating earthquake load, other variables should still be flexible.

This paper has shown the urgency to modify local building regulations to minimize the impact of earthquakes. Most local regulations unspecifically address the appropriate measures for minimizing the impact of earthquakes. Regulations for simple buildings are minimal, even though, in the case of many earthquake events, this building type contributes to a high number of fatalities and injuries.

The earthquakes in Palu 2019, Lombok 2018, and Yogyakarta 2006 are examples of earthquake that caused many fatalities and injuries because simple buildings were not designed and constructed to withstand this specific type of risk.

\section{CONCLUSIONS}

The new threat of 6.5 magnitude earthquake identified by the National Earthquake Centre in 2017 has not yet been fully incorporated in the building regulations of Surabaya. Simple buildings in Surabaya are the most unregulated building type in terms of minimizing the impact of potential earthquakes. In many cases in Indonesia, the simple building type significantly contributes to the number of fatalities and injuries. Thus, this unregulated condition may increase the risk in Surabaya. Consequently, the modification of current local regulations should ensure that the architectural and structural aspects of buildings effectively reduce the vulnerability of buildings.

This paper proposes a set of modifications to the current building regulations in Surabaya. Notably, the proposed regulations demand a feasible and robust calculation on the proposed building plans, namely, the chosen types of building shape, dilatation, building structures, and building materials. Currently, a set of comprehensive building regulations exist at the national level. Surabaya must follow these national regulations, which have specific requirements stipulated for all buildings in earthquake-prone areas.

Alternative and accommodative regulations, including a precise directive regulation, are required to ensure the practical application of the building regulations in Surabaya. This paper proposes two general mechanisms to improve them. First, Surabaya should recommend building directions on building shape, dilatation, and building materials. Second, building regulations should include obligatory criteria to ensure building safety, such as load factor analysis and building collapse scenarios. These two mechanisms are believed to have a high level of applicability and effectively minimize the impact of earthquakes. Further research is needed regarding the combination of variables in determining the building code to increase building resilience to earthquakes.

\section{ACKNOWLEDGEMENTS}

The authors express their gratitude to Institut Teknologi Sepuluh Nopember (ITS) - Surabaya for funding this research under the scheme of Penelitian Unggulan - Dana Lokal ITS, RISPRO LPDP Indonesian Ministry of Finance, and thank the stakeholders in Surabaya for providing extremely valuable and insightful responses during the interviewing process.

\section{REFERENCES}

Arnold C., Riba F. (1996), Architectural aspects of seismic resistant design. Proceedings of the $11^{\text {th }}$ World Conference on Earthquake Engineering. Elsevier Science Ltd. 2003. ISBN: o 08042822 3. URL: https://www.iitk.ac.in/nicee/wcee/article/11_2003.PD F. Accessed on: 08.09.2019

Arnold C., Reitherman R., Whitaker D. (1981), Building configuration and seismic design: The architecture of earthquake resistance [online], NASA STI/Recon Technical Report N, 82. URL: https://ui.adsabs.harvard.edu/abs/1981STIN...822950 6A. Accessed on 02.09.2019

Arya A. S., Boen T., Ishiyama Y. (2014), Guidelines for earthquake resistant non-engineered construction. IAEE, UNIESCO and IISEE, 199 p. ISBN: 978-92-3000032-5

Baird A., Palermo A., Pampanin S., Riccio P., Tasligedik A. S. (2011), Focusing on reducing the earthquake damage to façade systems. Bulletin of the New Zealand Society for Earthquake Engineering, June 2011. DOI: https://doi.org/10.5459/bnzsee.44.2.108-120 Barrett C. B., Constas M. A. (2014), Toward a theory of resilience for international development applications. Proceedings of the National Academy of Sciences of the United States of America, 111(40), 14625-14630. DOI: https://doi.org/10.1073/pnas.1320880111

BMKG (2010), Indonesia's Meteorology Climatology and Geophysics Board, Jakarta, Indonesia. URL: https://www.bmkg.go.id/gempabumi/antisipasigempabumi.bmkg. Accessed on 02.09.2019

Bungin B. (2010), Qualitative research: Communication, economics, public policy and other social sciences (Penelitian kualitatif: Komunikasi, ekonomi, kebijakan publik dan ilmu sosial lainnya). Kencana Prenada Media Grup. Jakarta. ISBN: 978-9793925-88-2 [Book in Indonesian]

Cross R. (2015), Nepal earthquake: A disaster that shows quakes don't kill people, buildings do [online]. The Guardian.

https://www.theguardian.com/cities/2015/apr/30/nep al-earthquake-disaster-building-collapse-resiliencekathmandu. Accessed on 02.09.2019 
Effendi Z. (2018), Surabaya is called the ideal location for investment, here are the reasons (Surabaya disebut lokasi ideal untuk investasi, Ini sebabnya). Detik News. https://news.detik.com/berita-jawa-timur/d-

4135580/surabaya-disebut-lokasi-ideal-untukinvestasi-ini-sebabnya. Accessed on 02.09.2019 [In Indonesian]

FEMA (2010), Earthquake-resistant design concepts an introduction to the NEHRP recommended seismic provisions for new buildings and other structures [online]. National Institute of Building Sciences, Building Seismic Safety Council, Washington DC, USA. URL: https://www.fema.gov/sites/default/files/202007/fema_earthquake-resistant-design-concepts_p-

749.pdf. Accessed on 02.09.2019

Firmansyah F., Pamungkas A., Larasati K. D. (2018), Spatial Pattern Analysis Using Spatial Metrics: A Case Study in Surabaya, Indonesia. IOP Conf. Series: Earth and Environmental Science 202. DOI: https://doi.org/10.1088/1755-1315/202/1/012018

Gautam D., Chaulagain H. (2016), Structural performance and associated lessons to be learned from world earthquakes in Nepal after April $25^{\text {th }} 2015$ (MW 7.8) Gorkha earthquake. Journal of Engineering Failure Analysis, 68, 222-243. https://doi.org/10.1016/j.engfailanal.2016.06.002

Giuliani H. (2000), Seismic resistant architecture: A theory for the architectural design of buildings in seismic zones. 12 WCEE; 2456. URL: https://www.iitk.ac.in/nicee/wcee/article/2456.pdf.

Accessed on: 15.07.2019

Groat L., Wang D. (2013), Architectural research methods, Second edition. John Wiley \& Sons Inc. Canada. ISBN: 978-0-470-90855-6

Indonesian Government (2002), Law No. 28 of 2002. Building (Bangunan Gedung). Indonesia [In Indonesian]

Indonesian Government (2005), National Government Regulation No. 36 of 2005, Implementing Regulations of Law No. 28 of 2002 concerning Buildings (Peraturan Pelaksanaan Undang-Undang Nomor 28 Tahun 2002 tentang Bangunan Gedung). Indonesia [In Indonesian]

Ipong L. G., Ongy E. E., Bales M. C. (2020), Impact of magnitude 6.5 earthquake on the lives and livelihoods of affected communities: The case of Barangay Lake Danao, Ormoc City, Leyte, Philippines. International Journal of Disaster Risk Reduction, 46, 19. DOI: https://doi.org/10.1016/j.ijdrr.2020.101520

Irawan D., Suswanto B., Iranata D., Amalia A. R. (2019), Development of building vulnerability assessment applications to earthquake loads. Location of the Surabaya and Waru Faults (Pengembangan aplikasi penilaian kerentanan gedung terhadap beban gempa. Lokasi Sesar Surabaya dan Waru). Research Report, Institut Teknologi Sepuluh Nopember, Indonesia [In Indonesian]
Juwana J. S. (2005), High-rise building systems guide for architects and building practitioners (Panduan sistem bangunan tinggi untuk arsitek dan praktisi bangunan). Erlangga. Jakarta. ISBN 9789797416850. [Book in Indonesian]

Koulali A., Susilo S., McClusky S., Meilano I., Cummins P., Tregoning P., Lister G., Efendi J., Syafii M. A. (2016), Crustal strain partitioning and the associated earthquake hazard in the Eastern SundaBanda Arc. Geophysical Research Letters, Advancing Earth and Space Science, 43(5). DOI: https://doi.org/10.1002/2016GL067941

Krippendorff K. (2004). Content analysis: An introduction to its methodology, Second edition. Sage Publications, Thousand Oaks, California. ISBN: 0-76191544-3 - ISBN: 0-7619-1545-1

Mack N., Woodsong C., MacQueen K., Guest G., Namey E. (2005), Qualitative research methods: A data collector's field guide. FHI-USAID. USA. ISBN: 0939704-98-6

Ministry of Public Works (2016), Regulation No. 05/PRT/M/2016. Building Permits (Izin Mendirikan Bangunan Gedung). Indonesia [In Indonesian]

Ministry of Public Works (2012), Indonesian National Standard (SNI) 1726-2012, Procedures for planning earthquake resistance for building and nonbuilding structures (Tata cara perencanaan ketahanan gempa untuk struktur bangunan gedung dan non gedung). Indonesia [In Indonesian]

Ministry of Public Works (2006), Regulation No. 29/PRT/M/2006. Guidelines for Building Technical Requirements (Pedoman Persyaratan Teknis Bangunan Gedung). Indonesia [In Indonesian]

Murty C. V. R., Goswami R., Vijayanarayanan A. R., Mehta V. V. (2012), Some concepts in earthquake behaviour of buildings [online]. Gujarat State Disaster Management Authority, Gandhinagar. URL: https://www.iitk.ac.in/nicee/IITK-

GSDMA/EBB_001_30May2013.pdf. Accessed on 06.09.2019

National Earthquake Centre (Pusat Gempa Nasional - PUSGEN) (2017), Map of sources and hazards of the 2017 Indonesian earthquake (Peta sumber dan bahaya gempa Indonesia tahun 2017). Research and Development Board, Indonesian Ministry of Public Works and Housing. ISBN: 978-602-5489-01-3

Pamungkas A., Ciptaningrum M. U., Jaelani L. M., Iranata D. (2019), Surabaya resilience index for potential earthquakes: An institutional perspective. Australasian Journal of Disaster and Trauma Studies, 23(1), 21-31. URL: $\quad$ http://trauma.massey.ac.nz/issues/20191/AJDTS_23_1_Pamungkas.pdf

Pamungkas A., Iranata D., Yuwono J., Jaelani L. M. (2019), An insight on Surabaya Development: Precolonials, colonial, post-colonial and current era. IOP Conf. Series: Earth and Environmental Science, 340 
(2019) 012002. DOI: https://doi.org/10.1088/17551315/340/1/012002

Riyanto W., Irawan D., Adi T. W. A., Iranata D., Amalia A. R. (2020), Earthquake vulnerability assessment of high-rise buildings in Surabaya using RViSITS Android Application. IOP Conf. Series: Materials Science and Engineering, 739 (2020) 012040. DOI: https://doi.org/10.1088/1757-

899X/739/1/012040

Srividhya K., Mohan A., Tholkapiyan M., Arunraj A. (2020), Earthquake disaster mitigation (EQDM) through engineering design. Materials Today: Proceedings, 22, 1074-1077. DOI: https://doi.org/10.1016/j.matpr.2019.11.303

Surabaya City Government (2018), Surabaya City Regulation No. 8 of 2018. Detailed Spatial Planning and Zoning Regulations of Surabaya City for 2018-2038 (Rencana Detail Tata Ruang dan Peraturan Zonasi Kota Surabaya Tahun 2018-2038). Surabaya [In Indonesian]

Surabaya City Government (2018), Surabaya Mayor Regulation No. 13 of 2018. Technical Guidelines for Building Permit Assessment (Pedoman Teknis Pelayanan Izin Mendirikan Bangunan). Surabaya [In Indonesian]

Surabaya City Government (2015), Surabaya City Housing and Settlement Area Development and Development Plan (Rencana Pembangunan dan Pengembangan Perumahan dan Kawasan Permukiman Kota Surabaya). Housing and Settlements, Public Works and Planning Agency, Surabaya. [In Indonesian] Surabaya City Government (2013), Surabaya City Regulation No. 6 of 2013. Amendment to Surabaya City Regional Regulation No. 7 of 2009 concerning
Buildings (Perubahan Atas Peraturan Daerah Kota Surabaya Nomor 7 tahun 2009 tentang Bangunan). Surabaya. [In Indonesian]

Surabaya City Government (2009), Surabaya City Regulation No. 7 of 2009). Building (Bangunan). Surabaya [In Indonesian]

Tamara M. (2011), Evaluation of building damage due to a major earthquake (Evaluasi kerusakan bangunan akibat gempa besar). Jurnal Ilmiah Media Engineering, 1(1), Maret 2011. ISSN 2087-9334 (1-9)

Tjokrodimulyo K. (2007), Concrete technology (Teknologi beton). First edition. KMTS FT UGM. Yogyakarta. ISBN 978-979-8219-23-8 [Book in Indonesian] Uniform Building Code (UBC) (1997), Structural engineering design provisions, 2, ICBO, USA. ISSN: o896-9655

World Bank Group (2015), Building regulation for resilience: Managing risks for safer cities. Global Facility for Disaster Risk Reduction (GFDRR). Washington DC, USA. URL: https://www.gfdrr.org/sites/default/files/publication/ BRR\%20report.pdf. Accessed on 02.08.2019

Zulkarnain R. C. (2016), The effect of land cover conversion on surface temperature changes in Surabaya city (Pengaruh perubahan tutupan lahan terhadap perubahan suhu permukaan di Kota Surabaya). Thesis. Dept. of Urban and Regional Planning, Institut Teknologi Sepuluh Nopember, Indonesia. [In Indonesian] 